\title{
Study of high fat feed for sturgeon fish
}

\author{
$D V$ Osepchuk $^{1}, N A$ Yurina $^{1, *}, E V$ Kuzminova $^{1}, A N$ Gneush $^{1,2}, D A$ Yurin $^{1}$, and $E A$ \\ $\operatorname{Maxim}^{1}$ \\ ${ }^{1}$ Krasnodar Research Centre for Animal Husbandry and Veterinary Medicine, Pervaya Liniya St., 1, \\ 350004, Krasnodar, Russian Federation \\ ${ }^{2}$ Kuban State Agrarian University named after I. T. Trubilin, Kalinina St., 13, 350044, Krasnodar, \\ Russian Federation
}

\begin{abstract}
The objective of the study is to analyze the growth and development of sturgeon fish when feeding trout food with a higher fat content and to conduct ultrasound diagnostics of the fish liver. The research was carried out on the basis of the fish farm of Albashi LLC, Leningradsky district, Krasnodar Territory. The experiment used juvenile Russian-Siberian sturgeon. The basal diet is sturgeon forage with a granule size of $3 \mathrm{~mm}$, produced by Aller Trident EX, trout forage from Aller Silver is also used for comparability of observation series. The experiment lasted 90 days. Aller Trident EX feed ingredients: vitamins, premixes and minerals, yeast, corn gluten, sunflower protein, wheat, wheat gluten, rapeseed oil, fish oil, fish meal, soy protein, soy. Although the increased content of fat for sturgeon fish in the compound feed contributes to an increase in their weight, but this occurs due to metabolic disorders and fat accumulation, which is also evidenced by an increase in juvenile waste in the experimental groups by 2.0$4.0 \%$ and the onset of pathological processes in the liver. Such fish can be used for commercial purposes and sale when the weight reaches $1000 \mathrm{~g}$.
\end{abstract}

\section{Introduction}

The industrial breeding of sturgeon fish to obtain marketable products is receiving increasing attention all over the world. The intensification of sturgeon breeding led to the emergence and spread of diseases of these fish species, the damage of which is also caused by diseases associated with metabolism, including fatty degeneration of the liver [1-3].

Due to its high functional specialization, the liver plays a significant role in maintaining the body's homeostasis. However, the accumulation of triacylglycerols, an increase in the level of easily oxidized lipids, and a decrease in the degree of unsaturation of phospholipids lead to a decrease in its functional activity in the processes of modification and detoxification of xenobiotics. The fish liver performs the main load under conditions of increased technogenic pressure, and the organism's ability to survive depends on its functional activity [4-8].

The vast majority of fish diseases are associated with the conditions of keeping and feeding. Basically, the treatment of fish diseases consists in their high-quality prevention.

\footnotetext{
* Corresponding author: naden8277@ mail.ru
} 
When growing sturgeon in aquaculture, much attention is paid to viral, bacterial, fungal, and invasive diseases. There is much less information on non-communicable diseases of sturgeon fish, in particular fatty hepatosis, which often occurs at industrial enterprises for the breeding of marketable fish, especially sturgeon. There is practically no systematic assessment of the state of the fish liver by a set of signs and indicators, especially intravital. Often, the diagnosis of fatty hepatosis in sturgeon is made after dissecting the fish [9-11].

The available literature contains material on the study of the structural and functional features of fish liver both in normal conditions and under various external influences. Structural and functional changes in the liver under the stressful action of physical and chemical factors are manifested in the form of granular degeneration, vacuolization of the cytoplasm of hepatocytes, necrobiosis and other disorders. In addition, there are morphological signs of hepatitis and cirrhosis, vascular disorders of various degrees, including hemorrhages and plasmorrhages, destruction and decay of tissues, dystrophy. Basically, the diagnosis of sturgeon hepatosis is based on their autopsy and morphological and histological studies, which leads to the death of valuable individuals.

The aim of the study is to analyze the growth and development of sturgeon fish when feeding trout food with a higher fat content and to conduct ultrasound diagnostics of the fish liver [12-15].

\section{Materials and methods}

The research was carried out on the basis of the fish farm of Albashi LLC, Leningradsky district, Krasnodar Territory. Albashi LLC has channel ponds with a total area of 2 and 35 hectares and a dug pond with a total area of 1 hectare, where carp, silver carp and European carp are grown. There are 2 fish-breeding modules for the basin keeping of sturgeon fish of all age-sex groups, a room for incubating eggs, cages in a channel pond for keeping large fish. The experiment is being carried out to conduct further, more in-depth studies on liver disfunction when feeding sturgeon feed with a high fat content.

Observations of sturgeon fish were carried out. The analysis of the behavioral and physiological characteristics of fish was carried out; individuals with pronounced signs of hepatosis were identified: unusual behavior (accumulation on the water surface), convulsive movements, changes in the structure of muscle tissue to the touch, the appearance of pigmented formations in the ventral region.

In the experiment, the sturgeon fish were fed with trout feed of a higher fat content. The experiment scheme is presented in table 1.

Table 1. Scheme of the experiment, $n=100$.

\begin{tabular}{|c|c|}
\hline Groups & Type of feed \\
\hline 1 (control) & $\begin{array}{c}\mathrm{BD}(\text { protein content }(\mathrm{P}) 47.0 \%, \text { fat }(\mathrm{F})-14.0 \%, \\
\text { metabolizable energy }(\mathrm{ME})-21.1 \mathrm{MJ})\end{array}$ \\
\hline 2 (experiment) & $\mathrm{BD}+30 \%$ trout feed $(\mathrm{P}-46.4 \%, \mathrm{~F}-15.8 \%, \mathrm{ME}-21.5 \mathrm{MJ})$ \\
\hline 3 (experiment) & $\mathrm{BD}+50 \%$ trout feed $(\mathrm{P}-46.0 \%, \mathrm{~F}-17.0 \%, \mathrm{ME}-21.7 \mathrm{MJ})$ \\
\hline 4 (experiment) & Trout feed $(\mathrm{P}-45.0 \%, \mathrm{~F}-20.0 \%, \mathrm{ME}-22.3 \mathrm{MJ})$ \\
\hline
\end{tabular}

The experiment used juvenile Russian-Siberian sturgeon. The basal diet is sturgeon forage with a granule size of $3 \mathrm{~mm}$, produced by Aller Trident EX, trout forage from Aller Silver is also used for comparability of observation series. The experiment lasted 90 days (see table 2). 
Table 2. Characteristics of Aller Trident EX feed.

\begin{tabular}{|c|c|}
\hline Items & Content \\
\hline Protein (\%) & 47 \\
\hline Fat (\%) & 14 \\
\hline Carbohydrates (\%) & 23.5 \\
\hline Ash (\%) & 6.7 \\
\hline Fiber (\%) & 2.8 \\
\hline Phosphorus (\%) & 1.1 \\
\hline Energy value (MJ) & 21.1 \\
\hline Digestible energy (MJ) & 17.8 \\
\hline
\end{tabular}

Aller Trident EX feed ingredients: vitamins, premixes and minerals, yeast, corn gluten, sunflower protein, wheat, wheat gluten, rapeseed oil, fish oil, fish meal, soy protein, soy (see table 3).

Table 3. Characteristics of Aller Silver feed.

\begin{tabular}{|c|c|}
\hline Items & Content \\
\hline Protein (\%) & 45 \\
\hline Fat (\%) & 20 \\
\hline Carbohydrates (\%) & 20 \\
\hline Ash (\%) & 7 \\
\hline Fiber (\%) & 2 \\
\hline Phosphorus (\%) & 1 \\
\hline Energy value (MJ) & 22.3 \\
\hline Digestible energy (MJ) & 19.1 \\
\hline
\end{tabular}

Aller Silver feed ingredients are: fish meal, fish oil, soy meal, hemoglobin meal, hydrolyzed protein, rapeseed, wheat, vitamins and mineral supplements.

The main indicators characterizing the growth rate of juvenile fish are its weight and feed consumption per unit of growth (feed coefficient). They reflect the influence of the studied fish feeding factors.

At the end of the experiment, a morphometric analysis of fish was carried out for 6 individuals from each group.

Also, ultrasound diagnostics of the liver was carried out using a DP-6900 device, Mindray (Mindray, China) - a digital portable ultrasound device.

\section{Results and discussion}

The main fish-breeding indicators of juvenile Russian-Siberian sturgeon rearing are presented in table 4 . 
Table 4. Main fish-breeding indicators of juvenile Russian-Siberian sturgeon rearing, $\mathrm{n}=100$.

\begin{tabular}{|c|c|c|c|c|}
\hline \multirow{2}{*}{ Items } & \multicolumn{4}{|c|}{ Group } \\
\cline { 2 - 5 } & 1 & 2 & 3 & 4 \\
\hline $\begin{array}{c}\text { Average weight of fish, g: } \\
\text { initial }\end{array}$ & $150.6 \pm 0.94$ & $150.9 \pm 1.02$ & $150.1 \pm 0.96$ & $150.2 \pm 1.00$ \\
\hline final & 371.2 & $\begin{array}{c}408.3 \\
\pm 4.11^{* * *}\end{array}$ & $\begin{array}{c}460.0 \\
\pm 5.00^{* * *}\end{array}$ & $\begin{array}{c}420.4 \\
\pm 4.18^{* * *}\end{array}$ \\
\hline In \% to control & 100.0 & 110.0 & 123.9 & 113.3 \\
\hline Gross weight gain, g & 220.6 & 257.4 & 309.9 & 270.2 \\
\hline $\begin{array}{c}\text { Average daily gain } \\
\text { (growth rate), g }\end{array}$ & 2.45 & 2.86 & 3.44 & 3.00 \\
\hline In \% to control & 100 & 116.7 & 140.5 & 122.5 \\
\hline Survival rate, \% & 100.0 & 100.0 & 98.0 & 96.0 \\
\hline \multicolumn{5}{|c|}{ Nutrients consumed per experiment per head } \\
\hline metabolizable energy, MJ & 84.4 & 86.0 & 86.8 & 89.2 \\
\hline protein, g & 188.0 & 185.6 & 184.0 & 180.0 \\
\hline fat, g & 56.0 & 63.2 & 68.0 & 80.0 \\
\hline \multicolumn{5}{|c|}{ Spent per 1 kg of weight gain: } \\
\hline feeds. kg & 1.81 & 1.55 & 1.29 & 1.48 \\
\hline metabolizable energy, MJ & 0.38 & 0.33 & 0.28 & 0.33 \\
\hline protein, g & 0.85 & 0.72 & 0.59 & 0.67 \\
\hline fat, g & 0.25 & 0.25 & 0.22 & 0.29 \\
\hline \multicolumn{5}{|c|}{ Note: ** P $\leq 0.01 ; * * *-\mathrm{P} \leq 0.001$} \\
\hline
\end{tabular}

The initial weight of fish when they were placed in the tanks was the same. However, significant differences were observed at the end of the growing period. The final weight of sturgeon in the second group increased significantly $(\mathrm{P} \leq 0.001)$ by $10.0 \%$, in the third - by $23.9 \%$, in the fourth - by $13.3 \%$.

Food consumption in all groups was the same, since the feeding was carried out in a standardized manner and amounted to $400 \mathrm{~g}$ for the entire period of the experiment per 1 fish. However, feed costs (feed ratio) per $1 \mathrm{~kg}$ of live weight gain were lower in the experimental groups by $14.4,28.7$ and $18.2 \%$, respectively.

The expenditure of metabolizable energy per $1 \mathrm{~kg}$ of fish weight gain in the control group was $0.38 \mathrm{MJ}$, in the second experimental group - by $13.2 \%$ lower, in the third group by $26.3 \%$ lower and in the fourth - by $13.2 \%$. Protein $-15.3 \%, 30.6 \%$ and $21.2 \%$ lower, respectively, in groups. Fat $-12.0 \%$ lower in the third experimental group and $16.0 \%$ higher in the fourth experimental group, compared with the control.

The fatness coefficient of juvenile Russian-Siberian sturgeon, calculated according to Fulton, is presented in table 5.

Table 5. Coefficient of fatness of juvenile Russian-Siberian sturgeon.

\begin{tabular}{|c|c|c|c|c|}
\hline \multirow{2}{*}{ Items } & \multicolumn{4}{|c|}{ Group } \\
\cline { 2 - 5 } & 1 & 2 & 3 & 4 \\
\hline \multirow{2}{*}{ Fish weight, $\mathrm{g}$} & 371.2 & 408.3 & 460.0 & 420.4 \\
& \pm 4.04 & $\pm 4.11^{* * *}$ & $\pm 5.00^{* * *}$ & $\pm 4.18^{* * *}$ \\
\hline Fish length, cm & $26.2 \pm 0.30$ & $26.0 \pm 0.25$ & $25.7 \pm 0.24$ & $25.3 \pm 0.22$ \\
\hline Fulton fatness & 2.06 & 2.32 & 2.71 & 2.60 \\
\hline In \% to control & 100.0 & 112.6 & 131.6 & 126.2 \\
\hline \multicolumn{7}{|c|}{ Note: $* * *-\mathrm{P} \leq 0.001$} \\
\hline
\end{tabular}

Fulton's fatness coefficient of juvenile Russian-Siberian sturgeon was higher in the second group - by $12.6 \%$, in the third group - by $31.6 \%$ and in the fourth group - by $26.2 \%$, compared with the control. 
The results obtained allow us to conclude that the use of trout feed in feeding juveniles of the Russian-Siberian sturgeon in the basins contributes to an increase in the growth rate of fish, but it is necessary to monitor the state of the fish for fatty liver tissue.

At the end of the experimental period, a morphometric analysis of fish with a mass equal to the average for the group was carried out (table 6).

Table 6. Results of morphometric analysis of the juvenile fish body $(n=6)$.

\begin{tabular}{|c|c|c|c|c|}
\hline \multirow{2}{*}{ Items } & \multicolumn{4}{|c|}{ Group } \\
\hline & 1 & 2 & 3 & 4 \\
\hline $\begin{array}{l}\text { Fish weight before } \\
\text { analysis, } g\end{array}$ & $\begin{array}{c}372.0 \\
\pm 5.5\end{array}$ & $\begin{array}{c}408.2 \\
\pm 6.2 * * *\end{array}$ & $\begin{array}{c}460.0 \\
\pm 4.9 * * *\end{array}$ & $\begin{array}{c}420.0 \\
\pm 5.0 * * *\end{array}$ \\
\hline $\begin{array}{l}\text { Gutted carcass weight } \\
\text { (with head and fins), g }\end{array}$ & $\begin{array}{c}334.4 \\
\pm 4.8\end{array}$ & $\begin{array}{c}367.8 \\
\pm 5.0 * * *\end{array}$ & $\begin{array}{c}412.6 \\
\pm 5.6^{* * * *}\end{array}$ & $\begin{array}{c}378.0 \\
\pm 6.0^{* * * *}\end{array}$ \\
\hline$\%$ of the initial weight & 89.9 & 90.1 & 89.7 & 90.0 \\
\hline $\begin{array}{c}\text { Weight, g: } \\
\text { head and fins, g }\end{array}$ & $\begin{array}{l}140.1 \\
\pm 2.8\end{array}$ & $\begin{array}{c}155.2 \\
\pm 3.7\end{array}$ & $\begin{array}{c}174.9 \\
\pm 3.3^{* * * *}\end{array}$ & $\begin{array}{c}163.3 \\
\pm 3.4 * * *\end{array}$ \\
\hline $\begin{array}{c}\text { \% by weight of gutted } \\
\text { carcass }\end{array}$ & 41.9 & 42.2 & 42.4 & 43.2 \\
\hline skin & $41.5 \pm 1.9$ & $47.1 \pm 1.2$ & $53.6 \pm 2.2 * *$ & $49.5 \pm 1.8^{* *}$ \\
\hline $\begin{array}{c}\text { \% by weight of gutted } \\
\text { carcass }\end{array}$ & 12.4 & 12.8 & 13.0 & 13.1 \\
\hline cartilage tissue & $32.1 \pm 1.5$ & $33.8 \pm 1.4$ & $37.1 \pm 1.6^{*}$ & $33.3 \pm 0.9$ \\
\hline $\begin{array}{c}\% \text { by weight of gutted } \\
\text { carcass }\end{array}$ & 9.6 & 9.2 & 9.0 & 8.8 \\
\hline muscle tissue & $\begin{array}{r}120.7 \\
\pm 2.2 \\
\end{array}$ & $\begin{array}{l}131.7 \\
\pm 2.7 * * \\
\end{array}$ & $\begin{array}{r}146.9 \\
\pm 3.0 * * * \\
\end{array}$ & $\begin{array}{r}131.9 \\
\pm 2.4 * * \\
\end{array}$ \\
\hline $\begin{array}{c}\% \text { by weight of gutted } \\
\text { carcass }\end{array}$ & 36.1 & 35.8 & 35.6 & 34.9 \\
\hline
\end{tabular}

With an increase in the mass indicators of the head, fins, skin, cartilaginous and muscle tissue in the experimental groups, it was found that, relative to the weight of the gutted carcass, the weight of the head and fins increased by $0.5-1.3 \%$, of the skin - by $0.6-0.7 \%$, the mass of cartilage tissue decreased - by $0.4-0.8 \%$ and muscle - by $0.3-1.2 \%$ in the experimental groups of fish relative to the control.

When analyzing the development of internal organs, attention was drawn to the fact that with an increase in the percentage of rich in fat feed, it causes a deterioration in the physiological state of the fish, and, accordingly, changes in the liver. The liver of fish of the third and fourth groups was somewhat enlarged, had a yellowish and creamy color, and had a loose consistency. In the first group, the fish liver had a pink color and a dense consistency. In the second group, the indicators were in an intermediate state. At the same time, an increase in liver indices was observed in the experimental groups.

As a result of ultrasound examination, isolated cases (no more than 3\%) of incipient liver dystrophy were found in the first group; in the second group - signs of incipient liver degeneration in $10 \%$ of fish; in the third group - signs of incipient liver degeneration in $30 \%$ of fish and in the fourth group - obvious signs of fatty liver disease in $65 \%$ of fish.

\section{Conclusions}

Based on the data obtained, it can be concluded that the increased content of fat in the compound feed for sturgeon fish contributes to an increase in their mass, however, this occurs due to metabolic disorders and fat accumulation, which is also evidenced by an increase in juvenile loss in the experimental groups by $2,0-4.0 \%$ and the onset of 
pathological processes in the liver. Such fish can be used for commercial purposes and sale when the weight reaches $1000 \mathrm{~g}$.

Further studies will be aimed at identifying the similarities and differences between healthy individuals and with fatty degeneration of the liver in terms of the content of a number of biochemical blood parameters using cluster analysis methods: total protein, urea, cholesterol, glucose, aminotransferase - AST and ALT, direct and total bilirubin.

The research was carried out within the framework of the grant of the President of the Russian Federation for state support of young Russian scientists on the topic: "Development of criteria for assessing the state of the liver of sturgeon fish" MD-1439.2020.11.

\section{References}

1. Józefiak A, Nogales-Mérida S, Rawski M, Kierończyk B, Mazurkiewicz J 2019 BMC Vet Res. 15348 doi: 10.1186/s12917-019-2070-y

2. Xu G, Xing W, Li T, Xue M, Ma Z, Jiang N, Luo L. 2019 BMC Microbiol. 19297 doi: 10.1186/s12866-019-1673-6

3. Geraylou Z, Souffreau C, Rurangwa E, D'Hondt S, Callewaert L, Courtin CM, Delcour J A, Buyse J, Ollevier F 2012 Fish Shellfish Immunol 4 718-24 doi: 10.1016/j.fsi.2012.06.010

4. Loponte R, Nizza S, Bovera F, De Riu N, Fliegerova K, Lombardi P, Vassalotti G, Mastellone V, Nizza A, Moniello G 2017 Res Vet Sci. 115 183-8 doi: 10.1016/j.rvsc.2017.04.017

5. Mikoiajczak Z, Rawski M, Mazurkiewicz J, Kierocczyk B, Jyzefiak D 2020 Animals (Basel) 10(6) 1031 doi: 10.3390/ani10061031

6. Rapatsa MM, Moyo NAG 2019 Fish Physiol Biochem 45(4) 1309-20 doi: 10.1007/s10695-019-00652-3

7. Abdel-Warith A A, Younis E M, Al-Asgah N A, Mahboob S Braz J 2020 Brazilian J of Biology 80(3) 535-43 doi: 10.1590/1519-6984.214763

8. Kryuchkov V N, Dubovskaya A V, Fomin I V 2006 Bulletin of ASTU 3(32) 94-100

9. Kryuchkov V N, Shaydullina Zh M 2007 South of Russia: ecology, development. 3 579

10. Dengyue Yuan, Yundi Gao, Xin Zhang, Bin Wang et al 2019 General and Comparative Endocrinolog 284(1) 113239 doi: 10.1016/j.ygcen.2019.113239.

11. Seunghyung Lee, Ozan Sonmez, Silas S O Hung, James G 2017 Animal Nutrition 3(1) 46-60 doi: 10.1016/j.aninu.2016.10.005

12. Silas S O Hung 2017 Animal Nutrition 3(3) 191-204 doi: 10.1016/j.aninu.2017.05.005

13. H C Wei, S J Xing, P Chen, X F Wu et al 2020 Fish \& Shellfish Immunology $106421-$ 30 doi: $\quad 10.1016 /$ j.fsi.2020.08.025

14. Farzin Jamalzad Falah, Houman Rajabi Islami, Mehdi Shamsaie Mehrgan 2020 Aquaculture Reports 17100391 doi: doi.org/10.1016/j.aqrep.2020.100391

15. Soheil Yousefi, Maryam Monsef Shokri, Hamid Allaf Noveirian, Seyed Hossein Hoseinifar 2020 Fish \& Shellfish Immunology 106 464-72 doi: 10.1016/j.fsi.2020.08.007 